\title{
Helicobacter pylori Upregulates Expression of Epidermal Growth Factor-related Peptides, but Inhibits Their Proliferative Effect in MKN 28 Gastric Mucosal Cells
}

\author{
Marco Romano, ${ }^{\ddagger}$ Vittorio Ricci,§ Anna Di Popolo, ${ }^{\star}$ Patrizia Sommi, ${ }^{\S}$ Camillo Del Vecchio Blanco, ${ }^{\ddagger}$ Carmelo B. Bruni, ${ }^{\star}$ \\ Ulderico Ventura, ${ }^{\S}$ Timothy L. Cover, Martin J. Blaser, $\|$ Robert J. Coffey, ${ }^{\Uparrow}$ and Raffaele Zarrilli* \\ *Dipartimento di Biologia e Patologia Cellulare e Molecolare "L. Califano," Centro di Endocrinologia ed Oncologia Sperimentale del \\ Consiglio Nazionale delle Ricerche, Università "Federico II," Napoli, Italy 80131; ${ }^{\ddagger}$ Dipartimento di Internistica Clinica e Sperimentale, \\ Divisione di Gastroenterologia, II Ateneo di Napoli, Napoli, Italy 80131; ${ }^{\S}$ Istituto di Fisiologia Umana, Università di Pavia, Pavia, Italy \\ 27100; "Department of Medicine, Division of Infectious Diseases, Vanderbilt University and Veterans Affairs Medical Center, Nashville, \\ Tennessee 37232; and ${ }^{\mathbb{T}}$ Department of Medicine, Division of Gastroenterology, Vanderbilt University and Veterans Affairs Medical \\ Center, Nashville, Tennessee 37232
}

\begin{abstract}
Acute exposure to Helicobacter pylori causes cell damage and impairs the processes of cell migration and proliferation in cultured gastric mucosal cells in vitro. EGF-related growth factors play a major role in protecting gastric mucosa against injury, and are involved in the process of gastric mucosal healing. We therefore studied the acute effect of $H$. pylori on expression of EGF-related growth factors and the proliferative response to these factors in gastric mucosal cells (MKN 28) derived from gastric adenocarcinoma. Exposure of MKN 28 cells to $H$. pylori suspensions or broth culture filtrates upregulated mRNA expression of amphiregulin (AR) and heparin-binding EGF-like growth factor (HB-EGF), but not TGF $\alpha$. This effect was specifically related to $H$. pylori since it was not observed with E. coli, and was independent of VacA, CagA, PicA, PicB, or ammonia. Moreover, $\mathrm{H}$. pylori broth culture filtrates stimulated extracellular release of AR and HB-EGF protein by MKN 28 cells. AR and HB-EGF dose-dependently and significantly stimulated proliferation of MKN 28 cells in the absence of H. pylori filtrate, but had no effect in the presence of $H$. pylori broth culture filtrates. Inhibition of AR- or HB-EGFinduced stimulation of cell growth was not mediated by downregulation of the EGF receptor since EGF receptor protein levels, EGF binding affinity, number of specific binding sites for EGF, or HB-EGF- or AR-dependent tyrosine phosphorylation of the EGF receptor were not significantly altered by incubation with $H$. pylori broth culture filtrates. Increased expression of AR and HB-EGF were mediated by an $\mathrm{H}$. pylori factor $>12 \mathrm{kD}$ in size, whereas antiproliferative effects were mediated by both VacA and a factor $<12 \mathrm{kD}$ in size. We conclude that $H$. pylori increases
\end{abstract}

Data from this work were presented in part at the Annual Meeting of the American Gastroenterological Association, San Francisco, CA, 18-24 May 1996, and are published in abstract form (1996. Gastroenterology. 110:834a).

Address correspondence to Marco Romano, M.D., and Raffaele Zarrilli, M.D., Ph.D., Dipartimento di Biologia e Patologia Cellulare e Molecolare "L. Califano," Università "Federico II" Via Pansini 5, Napoli, Italy 80131. Phone: 39-81-7462022; FAX: 39-81-7703285; E-mail: rafzarri@cds.unina.it

Received for publication 11 July 1997 and accepted in revised form 6 February 1998.

The Journal of Clinical Investigation

Volume 101, Number 8, April 1998, 1604-1613

http://www.jci.org mucosal generation of EGF-related peptides, but in this acute experimental model, this event is not able to counteract the inhibitory effect of $H$. pylori on cell growth. The inhibitory effect of $H$. pylori on the reparative events mediated by EGF-related growth factors might play a role in the pathogenesis of $H$. pylori-induced gastroduodenal injury. (J. Clin. Invest. 1998. 101:1604-1613.) Key words: Helicobacter pylori - heparin-binding EGF-like growth factor • amphiregulin • EGF receptor • gastric cell proliferation

\section{Introduction}

Helicobacter pylori is the major causative agent of chronic superficial gastritis, and plays a central role in the etiology of peptic ulcer disease in humans $(1,2)$. Moreover, epidemiological studies suggest that infection with $H$. pylori increases the risk for developing adenocarcinoma of the distal stomach (3, 4). The mechanisms whereby H. pylori causes disease are not completely elucidated. In addition to virulence factors common to all clinical isolates $(5,6)$, two factors have been described that are produced by $\sim 60 \%$ of wild-type isolates of $H$. pylori: $(a)$ an $\sim 90-\mathrm{kD}$ cytotoxin (VacA) that causes vacuole formation in epithelial cells (7-9), and (b) a 120-140-kD immunodominant protein (CagA; references 10 and 11). Essentially, all $H$. pylori strains possess vacA, but those that have the cytotoxin phenotype are referred to as $\mathrm{Tox}^{+}$. In contrast, only $\sim 60 \%$ of wild-type $H$. pylori strains possess $\operatorname{cag} A$; all of these are $\mathrm{CagA}^{+}$. An increasing body of evidence indicates that, in western countries, $H$. pylori strains producing both CagA and cytotoxic VacA are preferentially associated with development of peptic ulcer disease and gastric cancer $(9,12,13)$. We have recently shown that $H$. pylori broth culture filtrates, besides causing vacuolating damage (14), also alter the processes of cell migration and proliferation in gastric mucosal cells in vitro (15).

EGF-related peptides are polypeptides that share structural homology and a similar spectrum of biological activities exerted through interaction with a common cell surface receptor (EGFr; reference 16). ${ }^{1}$ EGF-related growth factors prevent drug-induced damage to the rat gastric mucosa $(17,18)$ and stimulate epithelial cell migration and proliferation (19-21), the main processes involved in healing gastroduodenal ulceration (22). Moreover, increased expression of EGF-related

1. Abbreviations used in this paper: $\mathrm{AR}$, amphiregulin; $\mathrm{B}_{\max }$, total number of specific binding sites; EGFr, EGF receptor; GAPDH, glyceraldehyde-3-phosphate dehydrogenase; HB-EGF, heparin-binding EGF-like growth factor; rh, recombinant human. 
peptides and of EGFr follows gastric mucosal injury (23-25), thus supporting the concept that these peptides acting through the EGFr participate in recovery of gastric mucosal integrity after injury $(26,27)$. Whether $H$. pylori infection alters expression of EGF-related growth factors, and whether these peptides play any role in the host response to $H$. pylori infection have not been studied.

This study was therefore designed to determine whether $H$. pylori alters expression of any of the EGF receptor (EGFr) ligands and, if so, whether specific bacterial virulence factors were responsible for this effect. Herein, we demonstrate that H. pylori induces expression of amphiregulin (AR) and heparin-binding EGF-like growth factor (HB-EGF), but not TGF $\alpha$, in MKN 28 gastric mucosal cells, effects that are independent of several known bacterial virulence factors. In addition, we demonstrate that pretreatment of cells with $H$. pylori broth culture filtrate blocks the mitogenic effect of exogenous AR or HB-EGF by a mechanism independent of EGFr downregulation or inactivation.

\section{Methods}

Cell culture. MKN 28 cells are derived from a human gastric tubular adenocarcinoma (28), and show gastric-type differentiation $(29,30)$. Cells were grown in DMEM supplemented with $10 \%$ FCS and $1 \%$ antibiotic-antimycotic solution (Gibco Laboratories, Grand Island, $\mathrm{NY}$ ) at $37^{\circ} \mathrm{C}$ in a humidified atmosphere of $5 \% \mathrm{CO}_{2}$ in air. Cells were grown in 100-mm dishes for RNA extraction, and in 24-well dishes for proliferation and binding studies.

Bacterial strains and growth conditions. We have used the urease-positive $\mathrm{Tox}^{+} \mathrm{CagA}^{+}$wild-type $H$. pylori 60190 strain (ATCC 49503) and isogenic mutants in which vacA, $\operatorname{cag} A, v a c A$, and $\operatorname{cag} A$, pic $A$, or pic $B$ genes were disrupted by insertional mutagenesis $(8,31-$ 33). We also used the $\operatorname{Tox}^{-} \mathrm{CagA}^{-} H$. pylori strain $\mathrm{Bx} 2 \mathrm{U}^{+}$and its urease-negative mutant $\mathrm{Bx} 2 \mathrm{U}^{-}$(provided by F. Megraud, Bordeaux, France) and the CCUG $17874\left(\mathrm{Tox}^{+} \mathrm{CagA}^{+}\right.$) strain (from the culture collection of the University of Goteborg, Goteborg, Sweden). Bacteria were grown in brucella broth supplemented with 5\% FCS (Gibco Laboratories) for $24-36 \mathrm{~h}$ at $37^{\circ} \mathrm{C}$ in a thermostatic shaker under microaerobic conditions. As previously described (14), when the bacterial suspensions reached $1.2 \mathrm{OD} \mathrm{U}$ at $450 \mathrm{~nm}$, bacteria were removed by centrifugation, and the supernatants were sterilized by passage through a $0.22-\mu \mathrm{m}$ pore-size cellulose acetate filter (Nalgene Co., Rochester, NY) to obtain the broth culture filtrates. Broth culture filtrates from different bacterial strains and different preparations from the same strain were standardized by growing the bacterial suspensions until they reached an $\mathrm{OD}$ of $1.2 \mathrm{U}$ at $450 \mathrm{~nm}$, which corresponds to a bacterial concentration of $5 \times 10^{8} \mathrm{CFU} / \mathrm{ml}$. In the experiments with dialyzed broth culture filtrates, aliquots of both $H$. pylori broth culture filtrates and control filtrates were dialyzed against HBSS for $36 \mathrm{~h}$ in dialysis tubing with a $12-\mathrm{kD}$ cutoff (Sigma Chemical Co., Milano, Italy). The presence or absence of VacA and/or CagA in H. pylori cells or filtrate was verified by means of SDS-PAGE followed by immunoblotting with anti-VacA or anti-CagA polyclonal antisera ( 7 , $34)$. In the experiments with bacterial suspensions, cells were incubated with bacterial preparations at a concentration of $5 \times 10^{7} \mathrm{CFU} /$ $\mathrm{ml}$ in DMEM supplemented with $10 \%$ FCS.

RNA isolation and Northern analysis. Total RNA was isolated from MKN 28 cells by the guanidinium thiocyanate acid-phenol procedure (35) and subjected to Northern analysis as described previously (36). In brief, $10 \mu \mathrm{g}$ of total RNA per lane was separated by electrophoresis in $1 \%$ agarose-formaldehyde gels. RNA was transferred to Hybond- $\mathrm{N}^{+}$(Amersham Corp., Milano, Italy), cross-linked (UV Stratalinker-1800; Stratagene, La Jolla, CA), and hybridized to ${ }^{32} \mathrm{P}$-labeled cDNA probes. ${ }^{32} \mathrm{P}$-labeled isotopes were from Amersham
Corp. The TGF $\alpha$ probe was a 1.27-kb Eco RI cDNA (37), the HBEGF probe was a 1.102-kb Eco RI cDNA (38), the AR probe was a 0.87-kb Eco RI-HinD III cDNA of (39), and the glyceraldehyde3-phosphate dehydrogenase (GAPDH) probe was a 1.5-kb Bam HI cDNA (40). TGF $\alpha$, HB-EGF, and AR mRNA levels were normalized to mRNA levels of the constitutively expressed GAPDH gene. mRNA levels were quantitated by densitometric scanning of the autoradiograph using a Howtek Scanmaster-3 densitometer with RFL Print-TM software (Pharmacia Biotech, Cologno Monzese, Italy).

Collection of conditioned medium. Cells were grown to semiconfluency in serum-containing medium. Semiconfluent monolayers were then washed twice with PBS and incubated for $24 \mathrm{~h}$ with broth culture filtrate from the H. pylori 60190 (wild-type) strain or with control (uninoculated) filtrate diluted 1:3 in serum-free medium. At the end of the incubation period, conditioned medium was harvested, centrifuged $\left(4,000 \mathrm{~g}\right.$ for $20 \mathrm{~min}$ at $\left.4^{\circ} \mathrm{C}\right)$ and concentrated using Centricon 3 microconcentrators (Amicon, Inc., Beverly, MA).

Preparation of cell extracts and immunoprecipitation. At the end of the incubation period, cells were washed twice with ice-cold PBS and incubated for $20 \mathrm{~min}$ at $4^{\circ} \mathrm{C}$ in lysis buffer containing $25 \mathrm{mM}$ Tris$\mathrm{HCl}(\mathrm{pH} 8.0), 150 \mathrm{mM} \mathrm{NaCl}, 10 \mathrm{mM}$ sodium pyrophosphate, $1 \mathrm{mM}$ sodium orthovanadate, $1 \mathrm{mM}$ PMSF (Sigma Chemical Co., Milano, Italy), $1 \%$ (vol $/ \mathrm{vol}$ ) Triton X-100, and $0.3 \mu \mathrm{g} / \mathrm{ml}$ aprotinin (Sigma Chemical Co.). Cells were dislodged with a cell scraper. The lysates were cleared by microfuging at $14,000 \mathrm{rpm}$ for $20 \mathrm{~min}$ at $4^{\circ} \mathrm{C}$. Immunoprecipitation was as described by Auricchio et al. (41). In brief, $1 \mathrm{ml}$ of lysate was diluted with lysis buffer to a final concentration of $1 \mathrm{mg} / \mathrm{ml}$ and incubated for $1 \mathrm{~h}$ with $5 \mu \mathrm{g}$ of rabbit anti-mouse IgG (Sigma Chemical Co.) and $40 \mu \mathrm{l}$ of protein G-Sepharose (50\% suspension; Pharmacia Biotech Inc., Cologno Monzese, Italy). The samples were centrifuged, and supernatants were incubated overnight with $3 \mu \mathrm{g} / \mathrm{ml}$ of anti-EGFr mouse monoclonal antibody, clone LA22 (Upstate Biotechnology Inc., Lake Placid, NY). Each sample was added to $100 \mu \mathrm{l}$ of protein G-Sepharose (50\% suspension), and was incubated for an additional hour. The samples were centrifuged, the pellets were washed with lysis buffer, and the proteins were eluted by boiling in Laemmli sample buffer.

Western blot analysis. After electrophoresis, proteins were blotted by electrotransfer to BA $850.45-\mu \mathrm{m}$ protan nitrocellulose filters (Schleicher \& Schuell, Inc., Dassel, Germany). After blocking with $10 \%$ BSA in TTBS (10 mM Tris, pH 7.5, $150 \mathrm{mM} \mathrm{NaCl}, 0.05 \%$ Tween 20), filters were probed with specific antibodies, and protein was visualized with peroxidase-coupled secondary antibody using the enhanced chemiluminescence detection system (ECL; Amersham Corp, Milano, Italy). The antibodies used in our studies were as follows: 2998 rabbit polyclonal anti-human HB-EGF antibody (42) kindly provided by Dr. M. Klagsbrun (Boston, MA); a rabbit polyclonal antibody directed against residues 26-44 of human AR (Neomarkers, Fremont, CA); a mouse monoclonal antiphosphotyrosine antibody, clone 4G10 (Upstate Biotechnology Inc.); 1005 rabbit polyclonal anti-EGFr antibody (Santa Cruz Biotechnology Inc., Milano, Italy); and secondary anti-rabbit or anti-mouse $\operatorname{IgG}$ antibody conjugated to horseradish peroxidase (Amersham Corp., Milano, Italy). In the EGFr immunoprecipitation experiments, filters were first immunodetected with antiphosphotyrosine antibody, and then stripped in a buffer containing $62.5 \mathrm{mM}$ Tris-HCl, $\mathrm{pH} 6.8,2 \%$ SDS, and $100 \mathrm{mM}$ $\beta$-mercaptoethanol for $30 \mathrm{~min}$ at $65^{\circ} \mathrm{C}$, washed three times in TTBS, blocked, and reprobed with 1005 rabbit polyclonal anti-EGFr antibody.

Determination of $\left[{ }^{3} H\right]$ thymidine incorporation. $5 \times 10^{4}$ cells/well were seeded onto 24 -well dishes. $12 \mathrm{~h}$ after seeding, medium was removed and replaced with serum-deprived medium in order to synchronize cell cycles. $12 \mathrm{~h}$ later, cells were incubated with test solutions. After $21 \mathrm{~h}, 1 \mu \mathrm{Ci} / \mathrm{ml}\left[{ }^{3} \mathrm{H}\right]$ thymidine (Amersham Corp.) was added, and incubation was continued for an additional $3 \mathrm{~h}$. Cells were then washed twice with ice-cold PBS and, after trypsinization, were collected on glass fiber filter mats using an LKB automatic cell harvester before liquid scintillation counting, as described previously 
(43). $\left[{ }^{3} \mathrm{H}\right]$ Thymidine uptake was expressed in cpm/well. Viability of cells treated with $H$. pylori broth culture filtrates and that of cells treated with the control (uninoculated) filtrate were comparable, as assessed by the Trypan blue dye exclusion test (data not shown). Data are presented as mean \pm SEM of three experiments run in quadruplicate.

Binding assays. Cells were seeded onto 24-well dishes at the concentration of $5 \times 10^{4}$ cells/well. When monolayers were $50 \%$ confluent, cells received serum-free medium for $24 \mathrm{~h}$. Subsequently, cells were incubated with serum-free medium, uninoculated broth filtrate, or broth culture filtrate from H. pylori 60190 strain for $24 \mathrm{~h}$. Before the beginning of each assay, the cells were washed three times with $4^{\circ} \mathrm{C}$ chilled binding medium that consisted of Krebs-Ringer/ (2-hydroxy-ethyl)-1-piperazineethanesulfonic acid containing $0.5 \%$ BSA and adjusted to $\mathrm{pH}$ 7.4. 400- $\mu$ l aliquots of the binding medium containing $0.06 \mathrm{nmol} /$ liter $\left.{ }^{125} \mathrm{I}\right] \mathrm{EGF}$ (Amersham Corp.) with different concentrations of unlabeled recombinant human (rh) EGF, rhHB-EGF (Sigma Chemical Co.), or rhAR (R\&D Systems, Inc., Minneapolis, $\mathrm{MN}$ ) were added to each well. After equilibration at $4^{\circ} \mathrm{C}$ for $4 \mathrm{~h}$, the cells were then washed three times with $4^{\circ} \mathrm{C}$ binding medium to remove unbound $\left[{ }^{125} \mathrm{I}\right] \mathrm{EGF}$. The cultures were then solubilized by adding $1.0 \mathrm{ml}$ of $1 \mathrm{~N} \mathrm{NaOH}$ to each well. After $30 \mathrm{~min}$, the contents of each well were withdrawn and added to tubes for counting in a Beckman Gamma 5500 counter. Nonspecific binding, determined as radioactivity bound in the presence of $10^{-6} \mathrm{M}$ unlabeled EGF, HB-EGF, or AR, was subtracted from total binding to obtain specific binding. All data points are expressed as mean \pm SEM of three separate experiments performed in triplicate.

Statistics and calculations. In the cell proliferation experiments, the significance of differences was evaluated by ANOVA followed by Duncan's multiple range test. Differences were considered significant if $P<0.05$. Binding data were analyzed using the curve-fitting program EBDA/LIGAND (44).

\section{Results}

Effect of $H$. pylori on $T G F \alpha, H B-E G F$, and AR $m R N A$ expression in MKN 28 cells. Incubating MKN 28 cells with bacterial suspensions from the H. pylori 60190 (wild-type) strain for 4-48 h did not have any effect on TGF $\alpha$ mRNA expression. There was, however, a time-dependent increase in HB-EGF and AR mRNA content in these cells in response to $H$. pylori (Fig. 1). The increase in HB-EGF and AR mRNA expression was already evident after 4 and $12 \mathrm{~h}$ of treatment, respectively, reached a peak at $24 \mathrm{~h}$ (20-fold increase vs. control), and declined at $48 \mathrm{~h}$ (Fig. 1). To determine whether the increase in HB-EGF and AR mRNA expression was specific for $H$. pylori 60190, we evaluated the effect of a bacterial suspension from wild-type $H$. pylori strain CCUG 17874, and obtained comparable results (data not shown). Similar effects were obtained with bacterial suspensions and with broth culture filtrates from H. pylori 60190 or CCUG strains (data not shown). Therefore, in the subsequent experiments, we used $H$. pylori broth culture filtrates only.

Role of $H$. pylori virulence factors in upregulation of $H B$ EGF and $A R$ mRNA expression. To identify potential $H$. pylori virulence factors responsible for HB-EGF induction and AR mRNA expression, MKN 28 cells were incubated for $24 \mathrm{~h}$ with uninoculated broth filtrate (control) or with broth culture filtrates from $H$. pylori 60190 (wild-type) strain, or its isogenic mutants lacking $\operatorname{vac} A, \operatorname{cag} A, \operatorname{vac} A$, and $\operatorname{cag} A$, picA, or picB. Fig. $2 A$ shows that a comparable increase in HB-EGF and AR mRNA expression was observed for all of the $H$. pylori strains tested. We also investigated whether urease-dependent ammonia generation might play a role in upregulating EGF-related

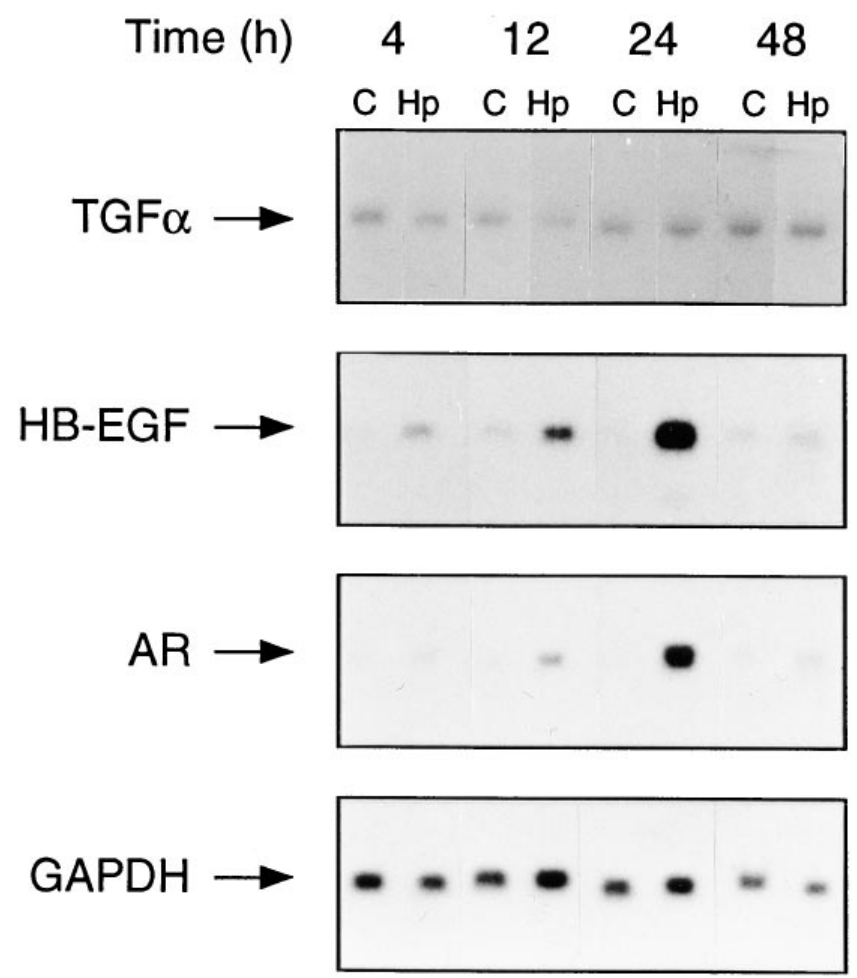

Figure 1. Time course of $H$. pylori effect on EGFr ligand mRNA expression in MKN 28 cells. Approximately $2 \times 10^{6}$ cells were incubated with DMEM (control) or with a bacterial suspension $\left(5 \times 10^{7}\right.$ $\mathrm{CFU} / \mathrm{ml}$ ) from $H$. pylori 60190 (wild-type) for up to $48 \mathrm{~h}$. Total RNA was isolated, Northern blots were performed using $10 \mu \mathrm{g}$ of total RNA per lane, and filters were sequentially hybridized to ${ }^{32} \mathrm{P}$-labeled cDNA probes for human TGF $\alpha$, HB-EGF, AR, or GAPDH, as previously described (36). The constitutively expressed GAPDH transcript was used to evaluate equivalence of RNA loading and transfer. A representative autoradiograph of four separate experiments is shown. C, control; Hp, H. pylori 60190.

peptides. Broth culture filtrates from a urease-positive $\left(\mathrm{Bx} 2 \mathrm{U}^{+}\right)$ strain and its urease-negative mutant $\left(\mathrm{Bx} 2 \mathrm{U}^{-}\right)$did not differ in their ability to induce HB-EGF or AR mRNA expression, nor did $\mathrm{NH}_{4} \mathrm{Cl}(4 \mathrm{mM})$ exert any effect on mRNA expression of either growth factor (Fig. $2 \mathrm{~B}$ ). This concentration of $\mathrm{NH}_{4} \mathrm{Cl}$ was similar to the ammonia concentration present when MKN 28 cells were incubated with broth culture filtrates from all the urease-positive H. pylori strains used (15). To determine whether similar effects were induced by other Gram-negative bacteria, we studied the effect of E. coli on the expression of growth factors. That incubation of cells with broth culture filtrate or cell suspension from a clinical $E$. coli isolate (ATCC 25922) did not have any effect on HB-EGF or AR mRNA expression compared with control (Fig. $2 B$ and data not shown) suggests that the observed effects were due to unique properties of $H$. pylori. We have previously shown that the vacuolating cytotoxin and a yet unidentified low $(<12 \mathrm{kD})$ molecular mass component inhibit proliferation of gastric mucosal cells (15). To evaluate whether this low molecular mass bacterial product might be responsible for upregulating EGFr ligand mRNA expression, we incubated MKN 28 cells with dialyzed (to eliminate products $<12 \mathrm{kD}$ ) or undialyzed broth culture filtrates from wild-type strain 60190 , or from its isogenic vac $\mathrm{A}^{-}$ mutant. HB-EGF and AR mRNA expression was increased to 

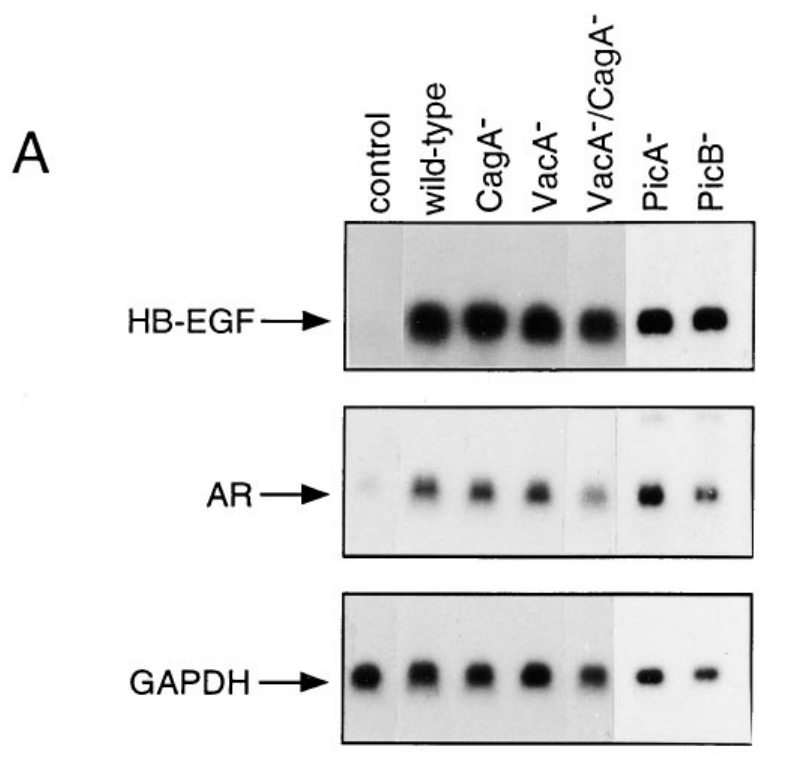

B

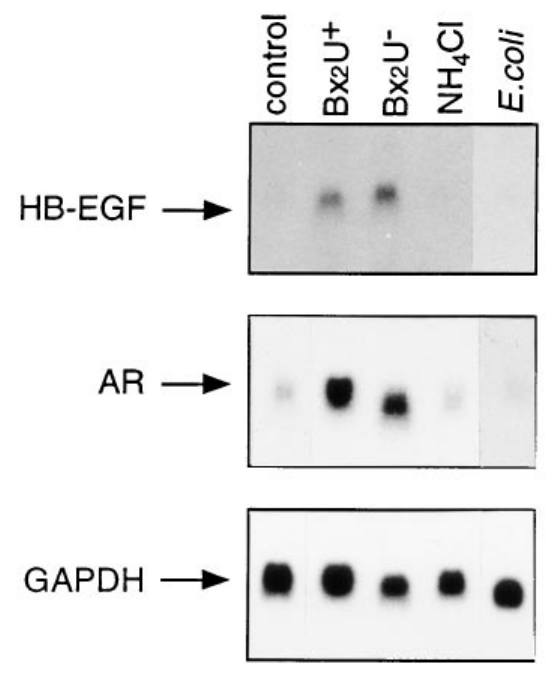

Figure 2. Role of H. pylori virulence factors in upregulating HBEGF and AR mRNA expression in MKN 28 cells. ( $A$ ) Approximately $2 \times 10^{6}$ cells were incubated for $24 \mathrm{~h}$ with uninoculated broth filtrate (control) or broth culture filtrates (each diluted 1:3 in culture medium, i.e., DMEM supplemented with $10 \%$ FCS) from $H$. pylori 60190 strain (wild-type) or its isogenic mutants $\left(\mathrm{CagA}^{-}, \mathrm{VacA}^{-}\right.$, $\mathrm{VacA}^{-} \mathrm{CagA}^{-}, \mathrm{PicA}^{-}$, or $\left.\mathrm{PicB}^{-}\right)$. (B) Approximately $2 \times 10^{6}$ cells were incubated for $24 \mathrm{~h}$ with uninoculated broth filtrate (control) or broth culture filtrates from H. pylori $\mathrm{Bx} 2 \mathrm{U}^{+}\left(\right.$Urease $\left.^{+}\right)$strain or its urease-negative mutant $\left(\mathrm{Bx} 2 \mathrm{U}^{-}\right.$; each diluted 1:3 in culture medium, i.e., DMEM supplemented with $10 \% \mathrm{FCS}$ ), or $4 \mathrm{mM} \mathrm{NH}_{4} \mathrm{Cl}$ or with E. coli (ATCC 25922 strain) broth culture filtrate. Isolation of total RNA, Northern blotting, and filter hybridization were identical to that described in Fig. 1. A representative autoradiograph of four separate experiments is shown.

a similar extent by dialyzed or undialyzed broth culture filtrates irrespective of expression of the vacuolating cytotoxin (Fig. 3), suggesting that a high ( $>12 \mathrm{kD})$ molecular mass component other than VacA is responsible for this effect.
Effect of H. pylori on HB-EGF and AR protein release in the conditioned medium of MKN 28 cells. To determine whether HB-EGF and AR protein production correlated with mRNA expression, conditioned medium from $H$. pylori-treated or -untreated (control) cells was analyzed by Western blot using antisera specific for HB-EGF and AR, respectively (Fig. 4). An HB-EGF immunoreactive peptide of $\sim 30 \mathrm{kD}$ (Fig. $4 A$ ) and an AR immunoreactive peptide of $\sim 10 \mathrm{kD}$ (Fig. $4 \mathrm{~B}$ ) were secreted in the conditioned medium from MKN 28 cells after $24 \mathrm{~h}$ of incubation with $H$. pylori 60190 broth culture filtrate, but were not detected in conditioned medium from MKN 28 cells treated with uninoculated broth filtrates. No HB-EGF or AR immunoreactive peptides were detected in H. pylori 60190 broth culture filtrate alone (data not shown). As expected, anti-human HB-EGF antibody and anti-human AR antibody also recognized recombinant human HB-EGF and AR peptides of 10 and $11 \mathrm{kD}$, respectively (Fig. 4). The differences in molecular mass between rhHB-EGF and the rhAR and HB-EGF and AR secreted by MKN 28 cells might be due to differential processing of the prepropeptides in MKN 28 cells. In fact, it has been demonstrated that human keratinocytes secrete different molecular mass forms of HB-EGF ranging from 14.5 to $30 \mathrm{kD}$ (45). Similarly, low (9.5 $\mathrm{kD})$ and high $(16.5 \mathrm{kD})$ molecular mass forms of AR have been described in human breast carcinoma cells (46).

Effect of $H$. pylori broth culture filtrates on $H B-E G F-$ or AR-induced MKN 28 cell proliferation. To determine whether HB-EGF or AR stimulates mitogenesis of MKN 28 cells, we studied the effect of adding rhHB-EGF (0.1-50 nM) or rhAR $(0.1-50 \mathrm{nM})$ on MKN 28 cell growth, as assessed by $\left[{ }^{3} \mathrm{H}\right]$ thymidine incorporation. Each peptide caused significant and dosedependent increases in DNA replication (Fig. 5). In particular, at a concentration $\geq 10 \mathrm{nM}, \mathrm{HB}-\mathrm{EGF}$ and AR caused a 2- and

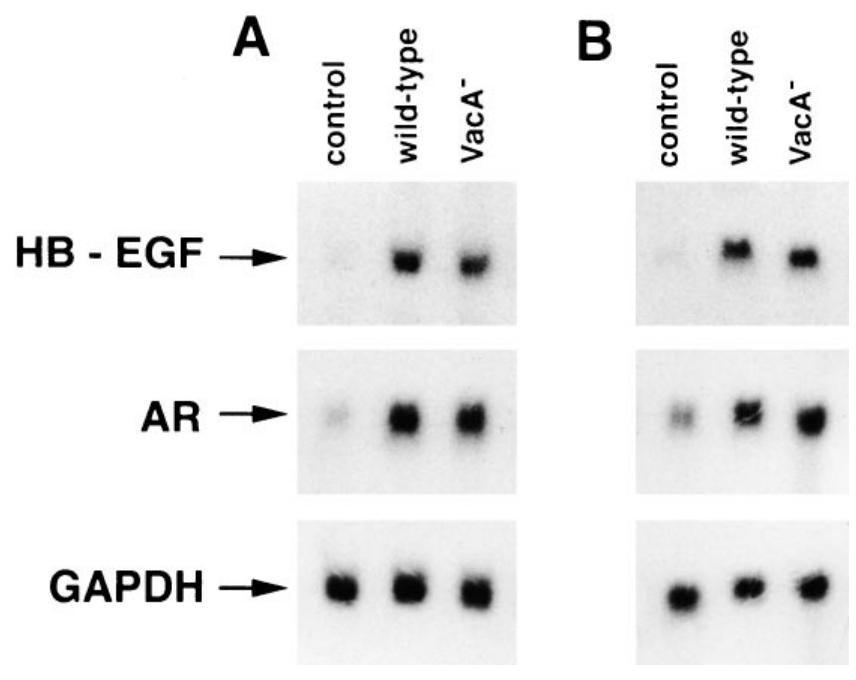

Figure 3. Comparative effect of undialyzed or dialyzed $H$. pylori broth culture filtrates on HB-EGF and AR mRNA expression in MKN 28 cells. Approximately $2 \times 10^{6}$ cells were incubated for $24 \mathrm{~h}$ with uninoculated broth filtrate (control) or broth culture filtrates (each diluted 1:3 in culture medium, i.e., DMEM supplemented with $10 \%$ FCS) from H. pylori 60190 strain (wild-type) or its isogenic vacA ${ }^{-}$mutant. $(A)$ Undialyzed filtrates; $(B)$ dialyzed filtrates. Isolation of total RNA, Northern blotting, and filter hybridization were as described in Fig. 1. A representative autoradiograph of three separate experiments is shown. 
A

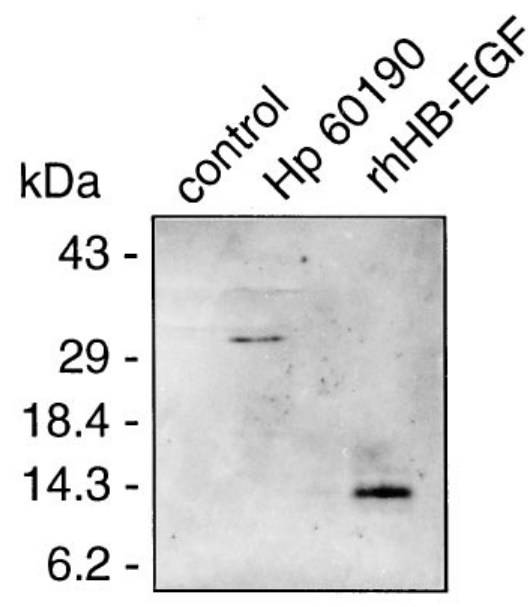

Figure 4. Effect of H. pylori broth culture filtrates on HB-EGF and AR protein levels in the conditioned medium of MKN 28 cells. Approximately $2 \times 10^{6}$ cells were incubated for $24 \mathrm{~h}$ with uninoculated broth filtrate (control) or broth culture filtrate from H. pylori 60190 strain (wild-type; each diluted 1:3 in serum-free medium). $50 \mu \mathrm{l}$ of concentrated conditioned medium was electrophoresed through $12 \%(A)$ or $15 \%(B)$ SDS-PAGE under nonreducing conditions and blotted to nitrocellulose filters. Immunodetection was performed using antihuman HB-EGF $(A)$ or anti-human AR $(B)$ antibody. The amount of samples loaded was standardized according to protein concentration. $10 \mathrm{ng}$ of rhHB-EGF or rhAR was loaded in the third lanes as controls. Migration of molecular weight markers is indicated on the left of each panel. a 2.5 -fold increase in $\left[{ }^{3} \mathrm{H}\right]$ thymidine uptake, respectively $(P<$ 0.05 vs. control).

We previously have shown that $H$. pylori broth culture filtrates cause a significant decrease in the proliferative activity of MKN 28 cells (15). This finding seemed to contradict our current data, which show that $H$. pylori induces HB-EGF and AR expression in MKN 28 cells, and that these cells prolif-

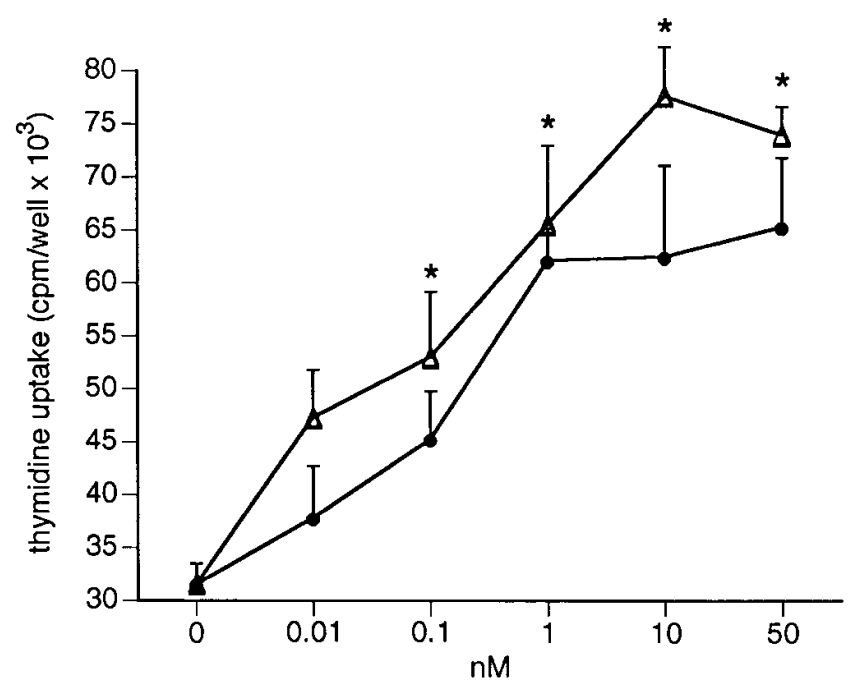

Figure 5. Effect of rhHB-EGF or rhAR on DNA replication in MKN 28 cells. $5 \times 10^{4}$ cells/well were seeded onto 24 -well dishes. $12 \mathrm{~h}$ after seeding, medium was removed and replaced with serum-free medium so as to synchronize cell cycles. $12 \mathrm{~h}$ later, cells were incubated with serum-free medium (control), rhHB-EGF $(\bullet ; 0.01-50 \mathrm{nM})$, or rhAR $(\triangle ; 0.01-50 \mathrm{nM})$. After $21 \mathrm{~h}, 1 \mu \mathrm{Ci} / \mathrm{ml}\left[{ }^{3} \mathrm{H}\right]$ thymidine was added, and incubation was continued for an additional $3 \mathrm{~h}$. Mean \pm SEM of three experiments run in quadruplicate. $* P<0.05$ vs. control $(0 \mathrm{nM})$. The basal $\left[{ }^{3} \mathrm{H}\right]$ thymidine uptake by MKN 28 cells in the absence of ligand (control) was $\sim 30,000 \mathrm{cpm} /$ well. erate in response to these two factors. Therefore, we studied whether $H$. pylori broth culture filtrates interfered with HBEGF- or AR-induced proliferation of MKN 28 cells. We confirmed that broth culture filtrates from $H$. pylori wild-type strain 60190 or its isogenic $v a c A^{-}$mutant nearly abolished the proliferative activity of cultured cells, and now found (Fig. $6 A$ ) that this effect was not counteracted by coadministration of rhHB-EGF or rhAR at a dose $(10 \mathrm{nM})$ that, when given alone, caused an approximately twofold increase in $\left[{ }^{3} \mathrm{H}\right]$ thymidine uptake. After pretreatment of cells with uninoculated broth filtrate, administration of rhHB-EGF $(10 \mathrm{nM})$ or rhAR $(10 \mathrm{nM})$ caused a significant increase $(P<0.05 \mathrm{vs}$. control $)$ in $\left[{ }^{3} \mathrm{H}\right]$ thymidine uptake of MKN 28 cells (Fig. $6 \mathrm{~B}$ ). In contrast, pretreatment with $H$. pylori broth culture filtrates abrogated growth factor-induced mitogenesis (Fig. $6 \mathrm{~B}$ ). We also evaluated whether dialyzed broth culture filtrates from cytotoxic (wild-type) or noncytotoxic $\left(\mathrm{VacA}^{-}\right)$H. pylori strains retained their ability to counteract EGF ligand-induced cell proliferation. We confirmed that dialyzed broth culture filtrate from the $H$. pylori wild-type strain retained its antiproliferative effect, and showed that this effect was not counteracted by coadministration of rhHB-EGF $(10 \mathrm{nM})$ or rhAR (10 nM; Fig. 7). On the other hand, dialyzed broth culture filtrate from the isogenic vac $\mathrm{A}^{-}$mutant lost its ability to inhibit basal as well as EGF-related peptide-stimulated cell growth (Fig. 7). These observations confirm that the vacuolating cytotoxin and a low $(<12 \mathrm{kD})$ molecular mass component play a role in inhibiting gastric cell proliferation, and suggest that both factors are important in counteracting EGF-related peptide-induced cell growth stimulation.

Effect of H. pylori broth culture filtrate on EGF binding affinity and on number of specific binding sites for EGF. Since the proliferative effects of HB-EGF and AR are mediated through the EGFr $(16,27)$, we hypothesized that $H$. pyloriinduced inhibition of EGF-related peptide-dependent cell growth might be mediated by EGFr downregulation. To address this issue, we performed experiments designed to quan- 
A

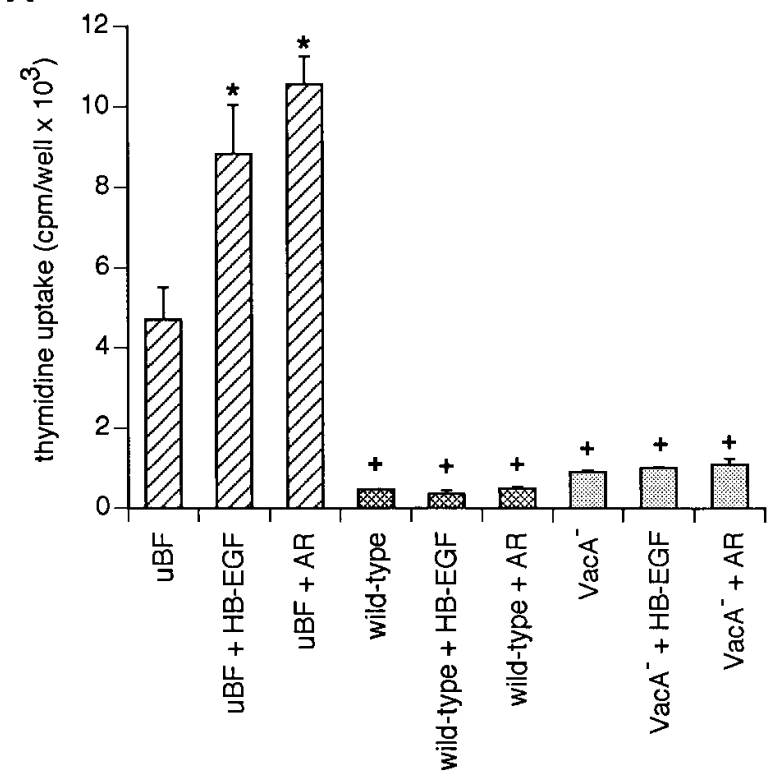

B

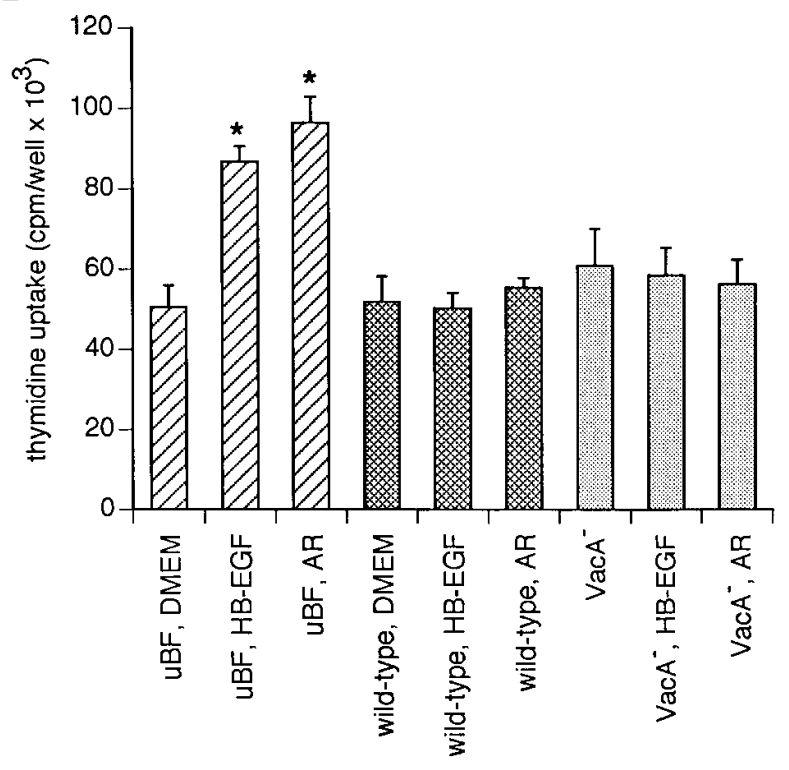

Figure 6. Effect of $H$. pylori broth culture filtrates on HB-EGF- or AR-induced stimulation of MKN 28 cell proliferation. $5 \times 10^{4}$ cells/well were seeded onto 24-well dishes. $12 \mathrm{~h}$ after seeding, medium was removed and replaced with serum-free medium for an additional $12 \mathrm{~h}$. $(A)$ cells were incubated for $24 \mathrm{~h}$ with control (uninoculated) broth filtrate $(u B F)$ or broth culture filtrate from H. pylori 60190 (wild-type) or its isogenic vac $A^{-}$ mutant $\left(\mathrm{VacA}^{-}\right)$strain without or with simultaneous exposure to rhHB-EGF $(10 \mathrm{nM})$ or rhAR $(10 \mathrm{nM})$. $(B)$ Cells were incubated for $24 \mathrm{~h}$ with uninoculated broth filtrate $(u B F)$ or broth culture filtrate from H. pylori 60190 (wild-type) or its isogenic $v a c A^{-}$mutant $\left(V a c A^{-}\right)$strains. At the end of the incubation period, supernatant medium was removed, and cells were incubated for an additional $24 \mathrm{~h}$ with serum-free medium (DMEM) without or with rhHB-EGF $(10 \mathrm{nM})$ or rhAR $(10 \mathrm{nM})$. In both experiments, $1 \mu \mathrm{Ci} / \mathrm{ml}\left[{ }^{3} \mathrm{H}\right]$ thymidine was added $3 \mathrm{~h}$ before the end of the last incubation period. Mean \pm SEM of three experiments run in quadruplicate. ${ }^{*} P<0.05$ vs. $\mathrm{uBF}(A)$ and $\mathrm{uBF}, \mathrm{DMEM}(B) ;{ }^{+} P<$ 0.05 vs. $\mathrm{uBF}(A)$.

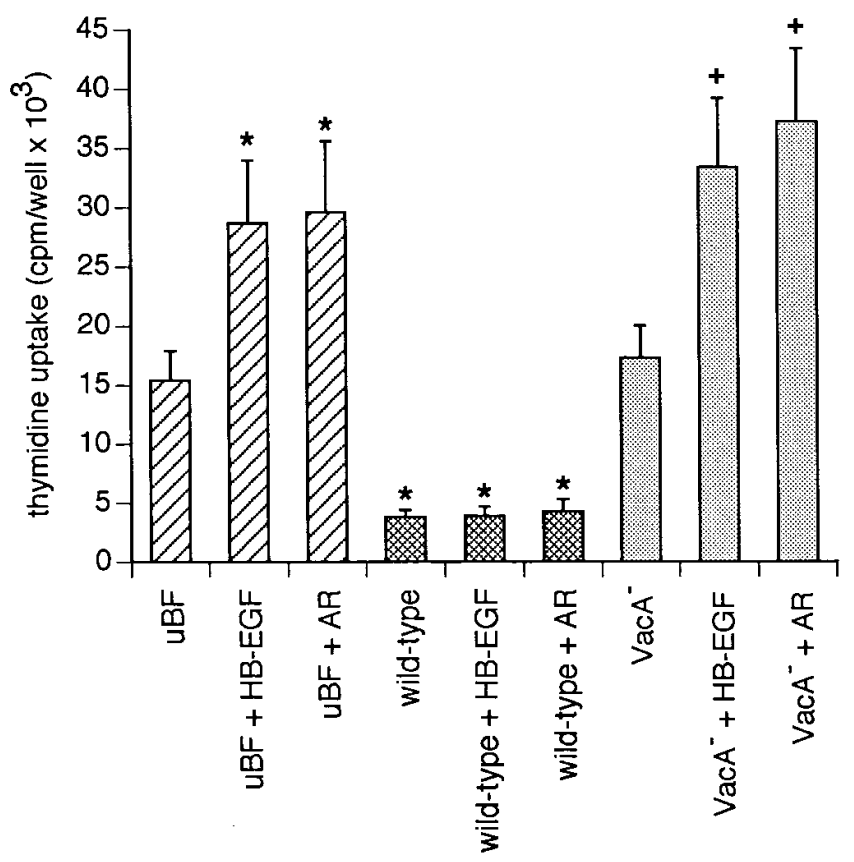

Figure 7. Effect of dialyzed H. pylori broth culture filtrates on HBEGF- or AR-induced stimulation of MKN 28 cell proliferation. $5 \times$ $10^{4}$ cells/well were seeded onto 24 -well dishes. $12 \mathrm{~h}$ after seeding, medium was removed and replaced with serum-free medium for an additional $12 \mathrm{~h}$. Cells were incubated for $24 \mathrm{~h}$ with dialyzed control (uninoculated) broth filtrate $(u B F)$ or dialyzed broth culture filtrate from tify binding of $\left.{ }^{125} \mathrm{I}\right] \mathrm{EGF}$ to MKN 28 cells after incubation with H. pylori 60190 (wild-type) broth culture filtrates or with control (uninoculated) broth filtrate. A competitive binding assay showed that $\left[{ }^{125} \mathrm{I}\right] \mathrm{EGF}$ binding was displaced in a dose-dependent manner by EGF, HB-EGF, or AR cold ligands (Fig. 8A). When the specific binding was evaluated by Scatchard plot analysis, a single class of high-affinity binding sites for EGF, HB-EGF, and AR was identified (Fig. $8 B$ and data not shown). The estimated $K_{\mathrm{d}}$ values for EGF, HB-EGF, and AR binding to MKN 28 cells incubated with uninoculated broth filtrate were $6.3 \times 10^{-10}, 1.1 \times 10^{-9}$, and $7.2 \times 10^{-9} \mathrm{M}$, respectively. The $K_{\mathrm{d}}$ value and total number of specific binding sites $\left(\mathrm{B}_{\max }\right)$ for EGF was not significantly altered in $H$. pylori-treated cells compared with controls (Table I). H. pylori-treated cells possessed a high number of surface EGFr ( 240,000 binding sites/cell), which was similar to findings for control cells.

Effect of H. pylori broth culture filtrates on tyrosine phosphorylation of the EGFr. As another approach to explain the inhibitory effect of $H$. pylori on HB-EGF- or AR-induced cell

H. pylori 60190 (wild-type) or its isogenic $v a c A^{-}$mutant $\left(V a c A^{-}\right)$ strain with or without simultaneous exposure to rhHB-EGF $(10 \mathrm{nM})$ or rhAR $(10 \mathrm{nM})$. After $21 \mathrm{~h}, 1 \mu \mathrm{Ci} / \mathrm{ml}\left[{ }^{3} \mathrm{H}\right]$ thymidine was added, and incubation was continued for an additional $3 \mathrm{~h}$. Mean \pm SEM of three experiments run in quadruplicate. ${ }^{*} P<0.05$ vs. uBF; ${ }^{+} P<0.05$ vs. $\mathrm{VacA}^{-}$. 
A

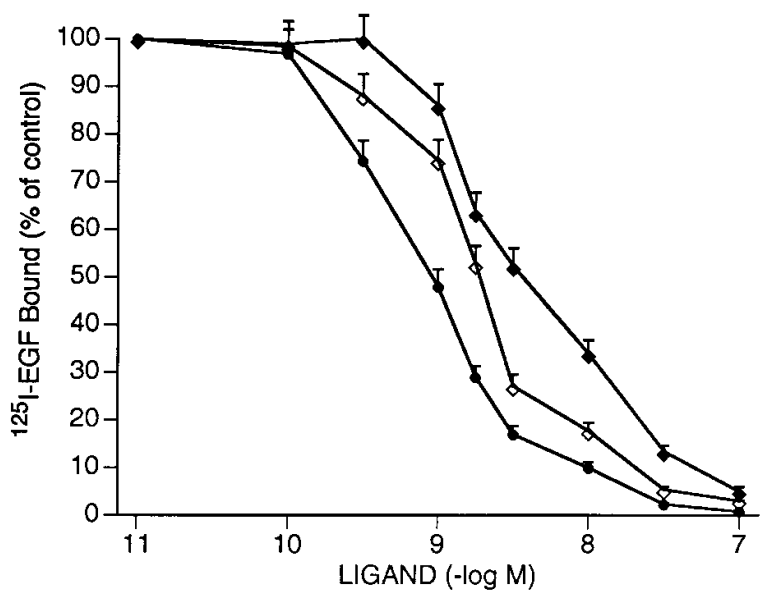

B

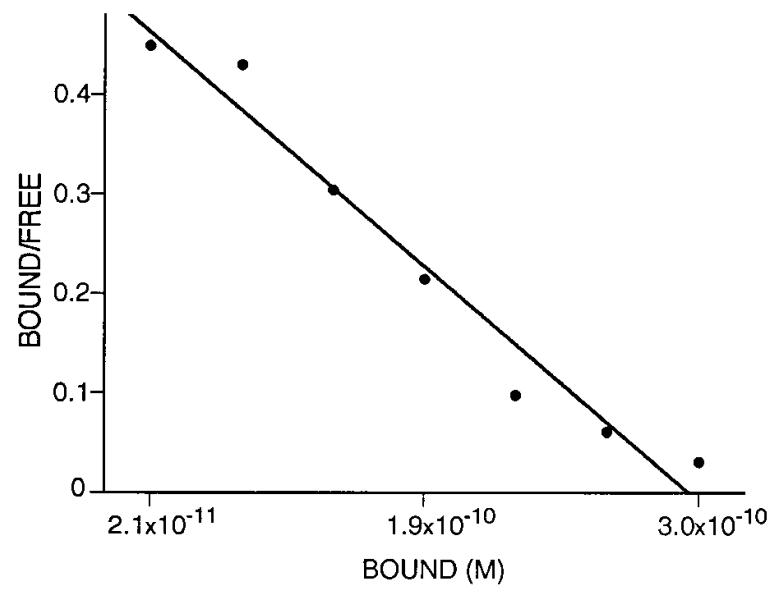

Figure 8. Effect of $H$. pylori on $\left[{ }^{125} \mathrm{I}\right] \mathrm{EGF}$ binding to MKN 28 cell monolayers. $(A)$ Competitive inhibition of $\left[{ }^{125} \mathrm{I}\right] \mathrm{EGF}$ binding to cultures of MKN 28 cells after incubation with broth culture filtrate from H. pylori 60190 strain in the presence of different concentrations of unlabeled EGF $(\bullet)$, HB-EGF $(\diamond)$, or AR $(\diamond)$. All values of $\left[{ }^{125} \mathrm{I}\right] \mathrm{EGF}$ with competitors were expressed relative to specific binding of $\left[{ }^{125} \mathrm{I}\right] \mathrm{EGF}$ without competitor $(100 \%$ control). Each point represents mean \pm SEM of quadruplicate measurements from three separate cell preparations. Divergence between quadruplicate values was $<15 \%$. (B) Representative Scatchard plot of [ $\left.{ }^{125} \mathrm{I}\right]$ EGF binding to MKN 28 cell monolayers in the presence of increasing concentrations of unlabeled EGF after treatment with broth culture filtrate from H. pylori 60190 strain. Each point is the mean of triplicate determinations from a representative experiment.

growth, we hypothesized that $H$. pylori broth culture filtrate might interfere with HB-EGF or AR-dependent EGFr activation. Treatment of MKN 28 cells with HB-EGF (10 nM) or AR $(10 \mathrm{nM})$ in the presence of either uninoculated broth filtrate or H. pylori 60190 broth culture filtrate induced tyrosine phosphorylation in proteins of $\sim 170$ and $70 \mathrm{kD}$ (Fig. 9 A, top). Also, the EGFr total protein levels were similar in cells treated with supernatants from $H$. pylori cultures or from uninoculated broth filtrate (Fig. 9 A, bottom). Immunoprecipitation of protein extracts with an anti-EGFr antibody followed by
Western blot analysis with an antiphosphotyrosine antibody showed that control (untreated) cells had undetectable levels of tyrosine-phosphorylated EGFr, whereas $H$. pylori treatment caused detectable tyrosine phosphorylation of the EGFr (Fig. 9 B). Also, H. pylori treatment did not alter HB-EGF- or AR-dependent EGFr tyrosine phosphorylation (Fig. $9 \mathrm{~B}$ ). In particular, densitometric analysis of the experiment shown in Fig. $9 B$ demonstrated that the antiphosphotyrosine/anti-EGFr ratio was close to 0 in control untreated cells, 0.6 in $H$. pyloritreated cells, and 3 and 2.5 vs. 4 and 3.5 after administration of rhHB-EGF $(10 \mathrm{nM})$ or rhAR $(10 \mathrm{nM})$ to control untreated cells and $H$. pylori-treated cells, respectively. Thus, there was no evidence that $H$. pylori filtrate inhibited activation of the EGFr.

\section{Discussion}

H. pylori infection is associated with development of gastroduodenal mucosal ulceration $(1,2)$, and with an increased risk of gastric adenocarcinoma in humans $(3,4)$. Host response and environmental factors are important in the pathogenesis of $H$. pylori-related gastroduodenal disease $(5,6)$. However, molecules expressed by $\sim 60 \%$ of wild-type isolates of $H$. $p y$ lori have been identified that may participate in the pathogenesis of $H$. pylori-induced disease (7-11). In particular, H. pylori strains preferentially associated with development of peptic ulcer or gastric adenocarcinoma express vacuolating cytotoxin activity (i.e., Tox $^{+} ; 7-9$ ) and an immunodominant antigen associated with the cytotoxin (i.e., CagA; references 10 and 11). Multiple genes in the cag island have recently been described, whose expression are necessary for cytokine production by gastric epithelial cells in vitro $(33,47)$.

EGF-related peptides have been shown to prevent druginduced damage to the stomach, and to accelerate healing of gastric mucosal ulcerations $(17,18)$, suggesting that EGF ligands play a major role in maintaining gastric mucosal integrity $(26,27,48,49)$. In particular, HB-EGF recently has been demonstrated to be expressed in the normal human gastric mucosa (50), and to be upregulated after acute injury to the rat stomach (51) or kidney (52). Therefore, we studied whether H. pylori might affect EGF-related peptide expression in gastric mucosal cells in vitro. Our data show that $H$. pylori upregulates expression of AR and HB-EGF at the mRNA and protein levels, effects not only observed with $H$. pylori suspensions, but also with broth culture filtrates, suggesting that it might be mediated by a soluble product released from the bacterium.

Table I. Effect of H. pylori 60190 (Wild-Type) Broth Culture Filtrate on EGF Binding Affinity $\left(K_{d}\right)$ and Number of Specific Binding Sites $\left(B_{\max }\right)$ in MKN 28 Cells

\begin{tabular}{lcc}
\hline & $K_{\mathrm{d}}$ & $\mathrm{B}_{\max }$ \\
\hline & $M \times 10^{-10}$ & $f M / 10^{4}$ cells \\
DMEM & $6.6 \pm 1.2$ & $3.3 \pm 0.6$ \\
Uninoculated broth filtrate & $6.3 \pm 1.5$ & $3.5 \pm 0.7$ \\
Hp 60190 BCF* & $6.6 \pm 0.9$ & $4.2 \pm 0.8$ \\
\hline
\end{tabular}

*Broth culture filtrate. Mean \pm SEM of four independent experiments. $K_{\mathrm{d}}$ and $\mathrm{B}_{\max }$ values were obtained using the EBDA/LIGAND program (44). 
A
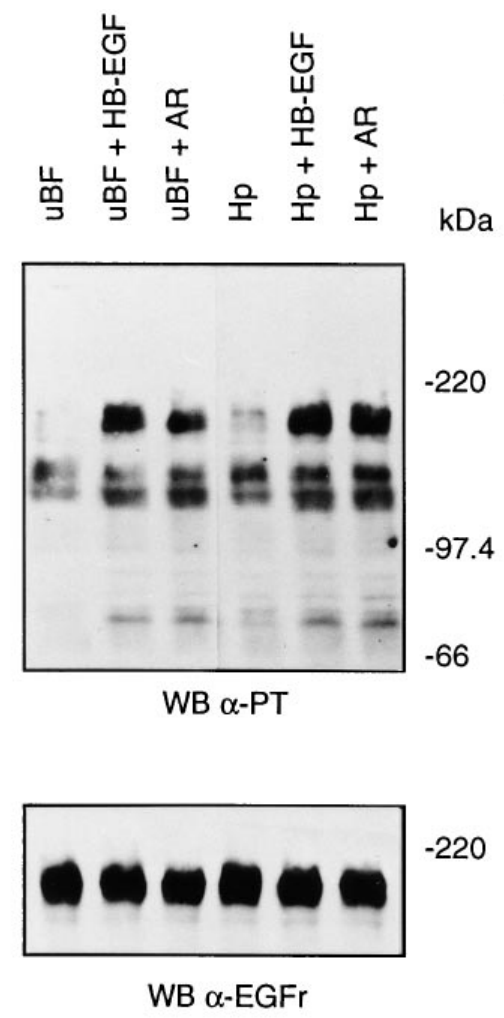

B
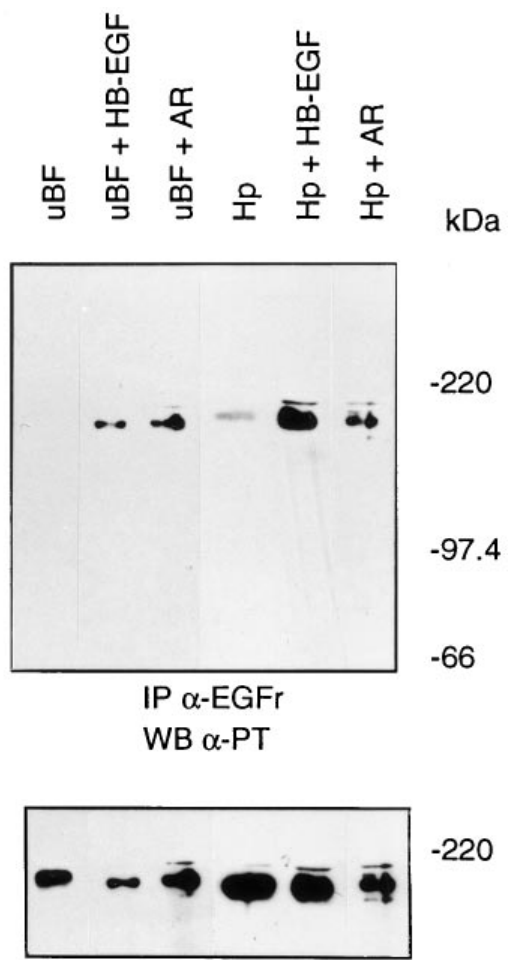

$-220$

Figure 9. Effect of $H$. pylori broth culture filtrates on tyrosine phosphorylation of EGFr. Approximately $2 \times 10^{6}$ cells were incubated for $24 \mathrm{~h}$ with uninoculated broth filtrate $(u B F)$, or $\mathrm{H}$. pylori 60190 broth culture filtrate $(\mathrm{Hp})$. Cells were then incubated for $10 \mathrm{~min}$ with uBF or $\mathrm{H}$. pylori broth culture filtrate in the absence or presence of rhHB-EGF $(10 \mathrm{nM})$ or rhAR $(10 \mathrm{nM})$. ( $A)$ Western blot analysis $(W B)$ of cell extracts $(50 \mu \mathrm{g} /$ sample) using an antiphosphotyrosine antibody ( $\alpha$-PT; top) or an antihuman EGFr antibody $(\alpha-E G F r$; bottom). (B) Immunoprecipitation of cell extracts ( $1 \mathrm{mg} / \mathrm{sample})$ with an antihuman EGFr antibody followed by Western blot analysis using an antiphosphotyrosine antibody (top) or an antihuman EGFr (bottom). Protein samples were electrophoresed through a 7.5\% SDS-PAGE under reducing conditions. The migration of molecular weight markers is indicated on the right of each panel.

Our data indicate that the H. pylori factor involved in upregulation of EGF-related peptide expression is $>12 \mathrm{kD}$, and that none of several known virulence factors, including $v a c A, c a g A$, pic $A$, or pic $B$, mediates this effect. Moreover, urease-generated ammonia does not seem to play a role in this effect since $\mathrm{NH}_{4} \mathrm{Cl}$ did not increase AR or HB-EGF mRNA expression, and a urease-negative $H$. pylori strain was as effective as its isogenic wild-type (urease positive) strain in upregulating AR and HB-EGF mRNA transcripts. The possibility that overexpression of AR and HB-EGF is a non specific phenomenon due to a component common to all Gram-negative bacteria is ruled out by the finding that $E$. coli did not affect AR or HB-EGF mRNA levels.

We also found that $H$. pylori treatment induced release of HB-EGF and AR protein in the conditioned media of cultured cells. An HB-EGF immunoreactive peptide of $30 \mathrm{kD}$ and an AR immunoreactive peptide of $10 \mathrm{kD}$ were identified. These different molecular weight forms of HB-EGF and AR have been found to be biologically active $(45,46)$. Secretion of HBEGF and AR in the conditioned medium together with the finding that either peptide dose-dependently stimulated gastric cell proliferation as assessed by $\left[{ }^{3} \mathrm{H}\right]$ thymidine incorporation suggests that these peptides may play an autocrine role in MKN 28 cell proliferation. Recent epidemiological studies in- dicate that $H$. pylori is involved in the development of adenocarcinoma of the distal stomach $(3,4)$. The pathogenetic mechanisms are not known, but increased proliferative activity of epithelial cells in gastric mucosa colonized by $H$. pylori might contribute $(53,54)$. Since increased expression of HB-EGF and AR has been described in gastrointestinal malignancies in humans $(55,56)$, we speculate that sustained overexpression of EGF-related peptides in persons colonized with $H$. pylori might overcome the acute inhibitory effect on cell growth exerted by $H$. pylori (15), thus leading to increased proliferation of gastric mucosal cells and, in turn, to development of gastric cancer. However, in vivo studies in $H$. pylori-colonized gastric mucosa are needed to verify this hypothesis.

We have previously shown in the same experimental model that $H$. pylori broth culture filtrates inhibited gastric mucosal cell proliferation (15). That $H$. pylori broth culture filtrates given either as a pretreatment or together with growth factors, completely abolished the growth stimulatory effect of AR or HB-EGF, suggests that increased production of these peptides after acute exposure to $H$. pylori is insufficient to counteract the marked inhibitory effect on cell growth exerted by $H$. $p y$ lori. We previously described that after dialysis with a $12-\mathrm{kD}$ cutoff, broth culture filtrate from $H$. pylori wild-type strain 60190 retained its ability to inhibit cell proliferation, whereas 
broth culture filtrate from its isogenic noncytotoxic strain did not. Moreover, inhibition of cell proliferation induced by dialyzed broth culture filtrate from the cytotoxic $H$. pylori strain was specifically counteracted by pretreatment with a neutralizing polyclonal antiserum raised against purified VacA (15). These observations suggest that $H$. pylori-induced inhibition of cell proliferation is due in part to the vacuolating cytotoxin, and in part to a low $(<12 \mathrm{kD})$ molecular mass component. Herein we have shown that after dialysis, the $H$. pylori wildtype strain retained its ability to counteract HB-EGF- or ARinduced cell growth, whereas the $H$. pylori noncytotoxic strain did not. This observation, together with the demonstration that neither the vacuolating cytotoxin nor a low molecular mass bacterial product are involved in upregulating HB-EGF or AR mRNA expression (Fig. 3), suggests that separate factors are involved in inducing EGF-related peptide expression, and in inhibiting their proliferative activity. In particular, upregulation of $\mathrm{HB}-\mathrm{EGF}$ and $\mathrm{AR}$ expression appears to be due to a high $(>12 \mathrm{kD})$ molecular mass component other than the vacuolating cytotoxin, since this effect is observed with both cytotoxic and noncytotoxic strains after dialysis. On the contrary, inhibition of basal as well as EGFr ligand-stimulated cell growth depends on the vacuolating cytotoxin, and is also contributed to by a low $(<12 \mathrm{kD})$ molecular mass bacterial product. That the cytotoxic strain retains its antiproliferative activity after dialysis, whereas the noncytotoxic strain does not, suggests that these separate factors might ultimately be the targets of different therapeutic interventions.

The biological effects of EGF-related peptides are mediated through interaction with a common cell membrane receptor (i.e., the EGFr; references 16 and 27). EGFr expression is upregulated after injury to the mucosa of the gastrointestinal tract (25). Inhibition of the tyrosine kinase specific for the EGFr impairs the protective effect of EGF against experimentally induced colitis in the rat (57). We found that either HBEGF or AR competed at high affinity for $\left[{ }^{125} \mathrm{I}\right] \mathrm{EGF}$ binding to MKN 28 cells, and that MKN 28 cells expressed a single class of binding sites for EGF with a $K_{\mathrm{d}}$ of $6.3 \times 10^{-10} \mathrm{M}$ and a $\mathrm{B}_{\max }$ of $\sim 210,000$ receptors/cell. This result is in partial agreement with Rutten et al., who found in primary culture of guinea pig gastric mucosal cells a single class of binding sites with a $K_{\mathrm{d}}$ of $2.6 \times 10^{-10} \mathrm{M}$ and a $\mathrm{B}_{\max }$ of $\sim 12,000$ receptors/cell (58). The higher EGFr expression in MKN 28 cells is similar to that reported for other tumor cell lines (59). Our data indicate that EGF binding affinity and the total number of specific binding sites for EGF are not significantly altered by incubation of MKN 28 cells with $H$. pylori broth culture filtrates, making it unlikely that downregulation of the EGFr plays a role in inhibiting EGF-related peptide-induced stimulation of cell growth by H. pylori.

Another mechanism of $H$. pylori-induced inhibition of growth factor-stimulated cell growth might be through inhibition of HB-EGF or AR-dependent activation of the EGFr (60). We therefore studied the effect of $H$. pylori on tyrosine phosphorylation of the EGFr induced by exogenous administration of HB-EGF or AR. Because of the comparable levels of either HB-EGF or AR-dependent tyrosine phosphorylation of the EGFr observed in monolayers treated with $H$. pylori broth culture filtrates and in control (untreated) monolayers, we speculate that $H$. pylori may act by altering the EGFr signal transduction pathway downstream to the activation of the receptor directly, or through activation of other signal transduc- tion pathways, such as the JNK/SAPK signalling pathway, that leads to inhibition of cell growth (61). Studies are underway in our laboratory to address this issue.

In conclusion, our study suggests that exposure of gastric mucosal cells to $H$. pylori leads to increased production of EGF-related growth factors. Induction of these growth factors is not sufficient to counteract the growth inhibitory effect exerted by $H$. pylori, at least in this acute experimental setting. Inhibition of EGF-related peptide-dependent cell growth does not seem to be due to downregulation of the EGFr, or to inhibition of EGFr activation. Finally, upregulation of EGF-related growth factors and inhibition of their stimulatory effect on cell growth appear to be mediated by separate $H$. pylori factors. We speculate that inhibition of reparative events mediated by EGF-related peptides might play a role in the pathogenesis of $H$. pylori-induced acute damage to the gastroduodenal mucosa in vivo.

\section{Acknowledgments}

We thank A. Migliaccio, M. Caraglia, M. Santoro (University of Napoli, Italy), and E. Solcia (University of Pavia, Italy) for helpful discussions and critical review of the manuscript, and $\mathrm{M}$. Berardone and F. D'Agnello for the art work.

This work was supported by grants from Associazione Italiana per la Ricerca sul Cancro, Comitato Nazionale Biotecnologie e Biologia Molecolare from Consiglio Nazionale delle Ricerche, Ministero dell' Università per la Ricerca Scientifica e Tecnologica, NCI CA46413 (R.J. Coffey), and by the Medical Research Service of the Department of Veterans Affairs. R.J. Coffey is a Clinical Investigator of the DVA.

\section{References}

1. Blaser, M.J. 1992. Hypotheses on the pathogenesis and natural history of Helicobacter pylori-induced inflammation. Gastroenterology. 102:720-727.

2. NIH Consensus Development Panel. 1994. Helicobacter pylori in peptic ulcer disease. JAMA. 272:65-75.

3. Nomura, A., G.N. Stemmermann, P.-H. Chyou, I. Kato, G.I. PerezPerez, and M.J. Blaser. 1991. Helicobacter pylori infection and gastric carcinoma in a population of Japanese Americans in Hawaii. N. Engl. J. Med. 325: 1132-1136.

4. Parsonnet, J., G.D. Friedman, D.P. Vandersteen, Y. Chang, J.H. Vogelman, N. Orentreich, and R.K. Sibley. 1991. Helicobacter pylori infection and the risk of gastric carcinoma. N. Engl. J. Med. 325:1127-1131.

5. Dunn, B.E. 1993. Pathogenic mechanisms of Helicobacter pylori. Gastroenterol. Clin. N. Am. 22:43-57.

6. Lee, A., J. Fox, and S. Hazell. 1993. Pathogenicity of Helicobacter pylori: a perspective. Infect. Immun. 61:1601-1610.

7. Cover, T.L., and M.J. Blaser. 1992. Purification and characterization of the vacuolating toxin from Helicobacter pylori. J. Biol. Chem. 267:10570-10575.

8. Ghiara, P., M. Marchetti, M.J. Blaser, M.K.R. Tummuru, T.L. Cover, E.D. Segal, L.S. Tompkins, and R. Rappuoli. 1995. Role of the Helicobacter pylori virulence factors vacuolating cytotoxin, $\mathrm{CagA}$, and urease in a mouse model of disease. Infect. Immun. 63:4154-4160.

9. Telford, J.L., A. Covacci, P. Ghiara, C. Montecucco, and R. Rappuoli. 1994. Unravelling the pathogenic role of Helicobacter pylori in peptic ulcer: potential new therapies and vaccines. Trends Biotechnol. 12:420-426.

10. Covacci, A., S. Censini, M. Bugnoli, R. Petracca, D. Burroni, G. Macchia, A. Massone, E. Papini, Z. Xiang, N. Figura, and R. Rappuoli. 1993. Molecular characterization of the $128-\mathrm{kDa}$ immunodominant antigen in Helicobacter pylori associated with cytotoxicity and duodenal ulcer. Proc. Natl. Acad. Sci. USA. 90:5791-5795.

11. Tummuru, M.K.R., T.L. Cover, and M.J. Blaser. 1993. Cloning and expression of a high-molecular-mass major antigen of Helicobacter pylori: evidence of linkage to cytotoxin production. Infect. Immun. 61:1799-1809.

12. Blaser, M.J., G.I. Perez-Perez, H. Kleanthous, T.L. Cover, R.M. Peek, P.-H. Chyou, G.N. Stemmermann, and A. Nomura. 1995. Infection with Helicobacter pylori strains possessing $\operatorname{cag} A$ is associated with an increased risk of developing adenocarcinoma of the stomach. Cancer Res. 55:2111-2115.

13. Xiang, Z., S. Censini, P.F. Bayeli, J.L. Telford, N. Figura, R. Rappuoli, and A. Covacci. 1995. Analysis of expression of CagA and VacA virulence factors in 43 strains of Helicobacter pylori reveals that clinical isolates can be di- 
vided into two major type and that CagA is not necessary for expression of the vacuolating cytotoxin. Infect. Immun. 63:94-98.

14. Ricci, V., P. Sommi, R. Fiocca, E. Cova, N. Figura, M. Romano, K.J. Ivey, E. Solcia, and U. Ventura. 1993. Cytotoxicity of Helicobacter pylori on human gastric epithelial cells in vitro: role of cytotoxin(s) and ammonia. Eur. J. Gastroenterol. Hepatol. 5:687-694.

15. Ricci, V., C. Ciacci, R. Zarrilli, P. Sommi, M.K.R. Tummuru, C. Del Vecchio Blanco, C.B. Bruni, T.L. Cover, M.J. Blaser, and M. Romano. 1996. Effect of Helicobacter pylori on gastric epithelial cell migration and proliferation in vitro: role of VacA and CagA. Infect. Immun. 64:2829-2833.

16. Barnard, J.A., R.D. Beauchamp, W.E. Russell, R.N. Dubois, and R.J. Coffey. 1995. Epidermal growth factor-related peptides and their relevance to gastrointestinal pathophysiology. Gastroenterology. 108:564-580.

17. Romano, M., W.H. Polk, J.A. Awad, C.L. Arteaga, L.B. Nanney, M.J. Wargovich, E.R. Krause, C.R. Boland, and R.J. Coffey. 1992. Transforming growth factor $\alpha$ protection against drug-induced damage to the rat gastric mucosa in vivo. J. Clin. Invest. 90:2409-2421.

18. Konturek, S.J., T. Brzozowski, J. Majka, A. Dembinski, A. Slomiany, and B.L. Slomiany. 1992. Transforming growth factor alpha and epidermal growth factor in protection and healing of gastric mucosal injury. Scand. J. Gastroenterol. 27:649-655.

19. Chen, M.C., A.T. Lee, and A.H. Soll. 1991. Mitogenic response of canine fundic epithelial cells in short term culture to transforming growth factor $\alpha$ and insulin-like growth factor. J. Clin. Invest. 87:1716-1723.

20. Ciacci, C., R. Zarrilli, V. Ricci, A. De Luca, G. Mazzacca, C. Del Vecchio Blanco, and M. Romano. 1996. Histamine H2 receptor antagonists stimulate proliferation but not migration of human gastric mucosal cells in vitro. Dig. Dis. Sci. 41:972-978.

21. Dignass, A.U., and D.K. Podolski. 1993. Cytokine modulation of intestinal epithelial cell restitution: central role of transforming growth factor beta. Gastroenterology. 105:1323-1332.

22. Silen, W. 1987. Gastric mucosal defense and repair. In Physiology of the Gastrointestinal Tract. 2nd ed. L.R. Johnson, editor. Raven Press, New York. 1055-1069.

23. Polk, W.H., P.J. Dempsey, W.E. Russell, P.I. Brown, R.D. Beauchamp, J.A. Barnard, and R.J. Coffey. 1992. Increased production of transforming growth factor $\alpha$ following acute gastric injury. Gastroenterology. 102:1467-1474.

24. Romano, M., C.A. Lesch, K.S. Meise, M. Veljaca, B. Sanchez, E.R. Krause, C.R. Boland, A. Guglietta, and R.J. Coffey. 1996. Increased gastroduodenal concentrations of transforming growth factor $\alpha$ in adaptation to aspirin in monkeys and rats. Gastroenterology. 110:1446-1455.

25. Tarnawski, A., J. Stachura, T. Durbin, J.I. Sarfeh, and H. Gergely. 1992. Increased expression of epidermal growth factor receptor during gastric ulcer healing in rats. Gastroenterology. 102:695-698.

26. Playford, R.J., and N.A. Wright. 1996. Why is epidermal growth factor present in the gut lumen? Gut. 38:303-305.

27. Uribe, J.M., and K.E. Barrett. 1997. Nonmitogenic actions of growth factors: an integrated view of their role in intestinal physiology and pathophysiology. Gastroenterology. 112:255-268.

28. Hojo, H. 1977. Establishment of cultured lines of human stomach cancer. Origin and their morphological characteristics. Niigata Igakukai Zasshi. 91: $737-752$

29. Romano, M., M. Razandi, S. Sekhon, W.J. Krause, and K.J. Ivey. 1988. Human cell line for study of damage to gastric epithelial cells in vitro. J. Lab. Clin. Med. 111:430-440.

30. Ricci, V., R. Fiocca, P. Sommi, E. Cova, M. Romano, O. Luinetti, P. Barattini, K.J. Ivey, E. Solcia, and U. Ventura. 1992. MKN 28 cell line: a useful tool to study human gastric epithelial cells. Pflug. Arch. 420:R182. (Abstr.)

31. Cover, T.L., M.K.R. Tummuru, P. Cao, S.A. Thompson, and M.J. Blaser. 1994. Divergence of genetic sequences for the vacuolating cytotoxin among Helicobacter pylori strains. J. Biol. Chem. 269:10566-10573.

32. Tummuru, M.K.R., T.L. Cover, and M.J. Blaser 1994. Mutation of the cytotoxin-associated $\operatorname{cag} A$ gene does not affect the vacuolating cytotoxin activity of Helicobacter pylori. Infect. Immun. 62:2609-2613.

33. Tummuru, M.K.R., S. Sharma, and M.J. Blaser 1995. Helicobacter pylori pic $B$, a homologue of the Bordetella pertussis toxin secretion protein, is required for induction of IL-8 in gastric epithelial cells. Mol. Microbiol. 18:867-876.

34. Cover, T.L., Y. Glupczynski, A.P. Lage, A. Burette, M.K.R. Tummuru, G.I. Perez-Perez, and M.J. Blaser. 1995. Serologic detection of infection with cagA + Helicobacter pylori strains. J. Clin. Microbiol. 33:1496-1500.

35. Chomczinski, P., and N. Sacchi. 1987. Single-step method of RNA isolation by acid guanidium thiocyanate-phenol-chloroform extraction. Anal. Biochem. 162:156-159.

36. Zarrilli, R., S. Pignata, M. Romano, A. Gravina, S. Casola, C.B. Bruni, and A.M. Acquaviva. 1994. Expression of insulin-like growth factor II (IGF-II) and IGF-I receptor during proliferation and differentiation of $\mathrm{CaCo}-2$ human colon carcinoma cells. Cell Growth Differ. 5:1085-1091.

37. Derynck, R., A.B. Roberts, M.E. Winkler, E.Y. Chen, and D.V. Goeddel. 1984. Human transforming growth factor- $\alpha$ : precursor structure and expression in E. coli. Cell. 38:287-297.

38. Higashiyama, S., J.A. Abraham, J. Miller, J.C. Fiddes, and M. Klagsburn. 1991. A heparin-binding growth factor secreted by macrophage-like cells that is related to EGF. Science.251:936-939.

39. Shoyab, M., G.D. Plowman, V.L. McDonald, J.F. Bradley, and G.J. Todaro. 1988. Amphiregulin: a bifunctional growth-modulating glycoprotein produced by the phorbol 12-myristate 13-acetate-treated human breast adenocarcinoma cell lile MCF7. Proc. Natl. Acad. Sci. USA. 85:6528-6532.

40. Tso, J.Y., X.H. Sun, T. Kao, S. Reece, and R. Wu. 1985. Isolation and characterization of rat and human glyceraldehyde-3-phosphate dehydrogenase cDNA: genomic complexity and molecular evolution of the gene. Nucleic Acids Res. 13:2485-2502.

41. Auricchio, F., M. Di Domenico, A. Migliaccio, G. Castoria, and A. Bilancio. 1995. The role of estradiol receptor in the proliferative activity of vanadate in MCF-7 cells. Cell Growth Differ. 6:105-113.

42. Dluz, S.M., S. Higashiyama, D. Damm, J.A. Abraham, and M. Klagsbrun. 1993. Heparin-binding epidermal growth factor-like growth factor expression in cultured fetal human vascular smooth muscle cells. J. Biol. Chem. 268: 18330-18334.

43. Zarrilli, R., M. Romano, S. Pignata, S. Casola, C.B. Bruni, and A.M. Acquaviva. 1996. Constitutive IGF-II expression interferes with the enterocytelike differentiation of CaCo-2 cells. J. Biol. Chem. 271:8108-8114.

44. McPerson, G.A. 1985. Analysis of radioligand binding experiments: a collection of computer programs for the IBM PC. J. Pharmacol. Methods. 14: 213-228.

45. Hashimoto, K., S. Higashiyama, H. Asada, E. Hashimura, T. Kobayashi, K. Sudo, T. Nagakawa, D. Damm, K. Yoshikawa, and N. Taniguchi. 1994. Heparin-binding epidermal growth factor-like growth factor is an autocrine growth factor for human keratinocytes. J. Biol. Chem. 269:20060-20066.

46. Johnson, G.R., S.A. Prigent, W.J. Gullick, and K. Stromberg. 1993. Characterization of high and low molecular weight forms of amphiregulin that differ in glycosylation and peptide core length. Evidence that the $\mathrm{NH}_{2}$-terminal region is not critical for bioactivity. J. Biol. Chem. 268:18835-18843.

47. Censini, S., C. Lange, Z. Xiang, J.R. Crabtree, P. Ghiara, M. Borodovski, R. Rappuoli, and A. Covacci. 1996. cag, a pathogenicity island of Helicobacter pylori, encodes type-I specific and disease-associated virulence factors. Proc. Natl. Acad. Sci. USA. 93:14648-14653.

48. Tarnawski, A., K. Tanque, A.M. Santos, and I.J. Sarfeh. 1995. Cellular and molecular mechanisms of peptic ulcer healing. Is the quality of mucosal scar affected by treatment? Scand. J. Gastroenterol. 30 210(Suppl.):9-14.

49. Konturek, P.C., T. Brzozowski, S.J. Konturek, H. Ernst, D. Drozdowicz, R. Pajdo, and E.G. Hahn. 1997. Expression of epidermal growth factor and transforming growth factor alpha during ulcer healing. Scand. J. Gastroenterol. 32:6-15.

50. Murayama, Y., J.-I. Miyagawa, S. Hiashiyama, S. Kondo, M. Yabu, K. Isozaki, Y. Kayanoki, S. Kanayama, Y. Shinomura, N. Taniguchi, and Y. Matsuzawa. 1995. Localization of heparin-binding epidermal growth factor-like growth factor in human gastric mucosa. Gastroenterology. 109:1051-1059.

51. Tsutsui, S., Y. Shinomura, Y. Higashimoto, S. Kanayama, Y. Miyazaki, T. Minami, Y. Murayama, S. Kitamura, S. Hiraoka, J. Miyagawa, et al. 1996. Induction of heparin-binding epidermal growth factor-like growth factor mRNA expression after acute gastric injury in rats. Gastroenterology. 110:1128 (Abstr.)

52. Homma, T., M. Sakai, H.F. Cheng, T. Yasuda, R.J. Coffey, Jr., and R.C. Harris. 1995. Induction of heparin-binding epidermal growth factor-like growth factor mRNA in rat kidney after acute injury. J. Clin. Invest. 96:1018-1025.

53. Lynch, D.A.F., N.P. Mapstone, A.M.T. Clarke, G.M. Sobala, P. Jackson, L. Morrison, M.F. Dixon, P. Quirke, and A.T.R. Axon. 1995. Cell proliferation in Helicobacter pylori associated gastritis and the effect of eradication therapy. Gut. 36:346-350.

54. Correa, P., and Y.-H. Shiao. 1994. Phenotypic and genotypic events in gastric carcinogenesis. Cancer Res. 54:1941s-1943s.

55. Naef, M., M. Yokoyama, H. Friess, M.W. Buchler, and M. Korc. 1996 Heparin-binding EGF-like growth factor is over-expressed in human gastric carcinoma. Gastroenterology. 110:565 (Abstr.)

56. Cook, P., M.R. Pittelkow, W.W. Keeble, R. Graves-Deal, R.J. Coffey, Jr., and G.D. Shipley. 1992. Amphiregulin messenger RNA is elevated in psoriatic epidermis and gastrointestinal carcinomas. Cancer Res. 523224-3227.

57. Lesch, C.A., and A. Guglietta. 1995. PD153035, an EGF receptor (EGFr) tyrosine-kinase specific inhibitor, reverses the effect of EGF on gastric secretion and TNBS-induced colitis in rats. Gastroenterology. 108:735. (Abstr.)

58. Rutten, M.J., P.J. Dempsey, C.A. Luttropp, M.A. Hawkey, B.C. Sheppard, R.A. Crass, C.W. Deveney, and R.J. Coffey. 1996. Identification of an EGF/TGF- $\alpha$ receptor in primary cultures of guinea pig gastric mucous epithelial cells. Am. J. Physiol. 270:G604-G612.

59. Aaronson, S.A. 1991. Growth factors and cancer. Science. 254:11461153.

60. Riese, D.J., E.D. Kim, K. Elenius, S. Buckley, M. Klagsbrun, G.D Plowman, and D.F. Stern. 1996. The epidermal growth factor receptor couples transforming growth factor- $\alpha$, heparin-binding epidermal growth factor-like factor, and amphiregulin to Neu, ErbB-3, and ErbB-4. J. Biol. Chem. 271: 20047-20052.

61. Coso, O.A., M. Chiariello, J.-C. Yu, H. Teramoto, P. Crespo, N. Xu, T. Miki, and J.S. Gutkind. 1995. The small GTP-binding proteins Rac1 and Cdc42 regulate the activity of the JNK/SAPK signalling pathway. Cell. 81:1137-1146. 